\title{
Hospital Acquired Infection: Bacteriological Profile of Species from Environmental Surfaces of Cotonou 5 Hospital in South Benin (West Africa)
}

\author{
F Cyr Doscoph Afle ${ }^{1 *}$, Alidéhou Jerrold Agbankpe ${ }^{2}$, Roch Christian Johnson ${ }^{1}$, \\ Olivia Houngbegnon ${ }^{3}$, Sègbè Christophe Houssou ${ }^{4}$ and Honoré Sourou Bankole ${ }^{3}$
}
${ }^{1}$ Interfacultary Center of Training and Research in Environment for Sustainable Development, University of Abomey-Calavi, 01 PO Box 1463 Cotonou, Benin
${ }^{2}$ Research Unit in Applied Microbiology and Pharmacology of Natural Substances, Research Laboratory in Applied Biology, Polytechnic School of Abomey-Calavi University, University of Abomey-Calavi, 01 PO Box 2009 Cotonou Benin ${ }^{3}$ Bacteriology Laboratory of the Ministry of Public Healt, 01 PO Box 418 Cotonou Benin ${ }^{4}$ Faculty of Human Sciences, University of Abomey-Calavi

*Corresponding author

\section{A B S T R A C T}

\begin{tabular}{|c|}
\hline Keywords \\
\hline $\begin{array}{l}\text { Healthcare- } \\
\text { associated } \\
\text { infections, Hospital } \\
\text { environment, Benin }\end{array}$ \\
\hline Article Info \\
\hline $\begin{array}{l}\text { Accepted: } \\
12 \text { March } 2018 \\
\text { Available Online: } \\
10 \text { April } 2018\end{array}$ \\
\hline
\end{tabular}

Hospital environment is sometimes the reservoir of pathogens that can be passed on to patients in different ways. The emergence of multi-resistant bacteria aggravates this situation, especially in a context of very limited therapeutic options. The objective of this study was to identify the bacterial species present on the environmental surfaces of the Cotonou 5 Hospital in order to control the contamination and the spread of pathogens. This aim was achieved by examining 165 samples, 135 (81.82\%) of which had positive bacterial culture. The frequency of isolation was predominant in the intensive care unit (95\%), emergency department $(95 \%)$ and paediatrics $(85 \%)$. In addition $49.77 \%$ of the positive bacterial cultures were Gram-positive and $50.20 \%$ were Gram-negative bacteria. Acinetobacter baumannii, Bacillus spp., Escherichia coli and Staphylococcus aureus were identified in all surveyed hospital units. Among the Gram-negative isolates, Enterobacteriaceae were more abundant (31.19\%), followed by Non-fermenting gramnegative bacilli (16.75\%). This study revealed that different bacterial species were present on the hospital surfaces of the Cotonou 5 Hospital. It is a reflection of the level of implementation of hospital hygiene rules and the risk of the resulting healthcare-associated infections. However, the spread of pathogenic strains can be controlled by appropriate hospital hygiene measures. 


\section{Introduction}

Healthcare-associated infections continue to be a major cause of morbidity and mortality for patients in hospitals (Weber et al., 2010). It is a public health problem that has important economic consequences as well (Defez et al., 2008; Hamza, 2010). The various pathogens of these infections sometimes have an endogenous or exogenous origin with various risk factors (Parneix, 2010; Alonso-Aguilar $e t$ al., 2017). The endogenous flora of patients is a significant source of nosocomial pathogens. However, about $20-40 \%$ of healthcareassociated infections are transmitted by the hands of health personnel previously contaminated by another infected patient (Weber et al., 2010). Health personnel are often a reservoir of pathogens and sometimes infect patients with Methicillin-resistant Staphylococcus aureus (MRSA) present in their nostrils (Ragini et al., 2018; Sangeetha et al., 2018). Despite advances in healthcare safety, the hospital environment contributes to the spread of pathogens (Oliveira and Damasceno, 2010). Thus, microbiological controls for the identification of germs in hospitals allow the resulting health problems to be managed and mitigated (Oliveira and Damasceno, 2010). In Benin, while healthcare-associated infections exist, they have not been extensively studied, and research on their magnitudes in hospitals is particularly limited. However, according to a study of patients admitted to a Benin hospital in $2012,9.84 \%$ of this population acquired a nosocomial infection (Ouendo et al., 2015). Of all the germs responsible for infection, bacteria play the most important role (Marty, 2010). The pathogens observed in the hospital are mainly staphylococci and gram-negative bacteria (Enterobacteriaceae, Pseudomonas, Acinetobacter and related bacteria) (Soussy, 2010). Non-fermenting Gram-negative bacilli (NFGNB) living in the hospital environment are also a major source of hospital infections
(Siddiqui et al., 2018). Other bacteria are multi-resistant and create real difficulties for health personnel, especially if their therapeutic options are limited (Cornejo-Juárez et al., 2015). Thus, MRSA has a particularly important progression in hospitals (Hsu et al., 1988), as these staphylococci and vancomycin-resistant enterococci (VRE) can survive for several days on hospital surfaces (Boyce, 2007).

According to Boyce et al., (1997), 27\% of the 350 surfaces sampled in the rooms of infected patients as a part of their investigation were contaminated with MRSA. For the safety of patient care, knowledge of the bacteriological quality of hospital surfaces is thus highly important.

This provides information on the presence of nosocomial pathogens and the quality of hygiene in the hospital environment (Oliveira and Damasceno, 2010; Galvin et al., 2012; Hassan et al., 2015). Thus, the aim of the present study was to determine the bacterial contamination of various surfaces of Cotonou 5 Hospital in a dynamic fight against healthcare-associated infections.

\section{Materials and Methods}

An analytical cross-sectional study was carried out from the surface samples of the Cotonou 5 hospital in South Benin (West Africa), in order to identify the presence of bacterial species.

The work spanned two months (March to April 2017). The samples were taken from various sites in the hospital environment. Services concerned were: Hospitalization adults, Maternity, Emergency services, Operating Theater, Intensive Care Unit. Bacteriological testing was carried out at the National Laboratory of Biomedical Analysis of the Ministry of Health (Benin). 


\section{Methods}

\section{Sample collection}

The 165 samples were taken at different environmental surfaces according to the hospital's survey services (Table 1). Samples were taken in the morning one hour after the cleaning and disinfection of the room. For some services (surgery room), the samples were taken after disinfection of the room without its prior use according to ISO 146981: 2003. The sterile swabs were moistened with sterile distilled water and passed in parallel striations on the surface by turning them slightly, then in perpendicular striations on the same zones.

Subsequently, the swabs were returned to their protective cases and transmitted to the laboratory within one hour. We obtained a total of 165 samples from the 54 selected sites across the 6 investigative services. The number of samples varied between 2 and 4 per site.

\section{Isolation}

The samples were emulsified in haemolysis tubes with $5 \mathrm{ml}$ of Brain Heart broth (BHB) and incubated at $37^{\circ} \mathrm{C}$ for 24 hours. Bacterial growth manifested in the form of turbidity. Each sample showing turbidity was streaked on Eosin Methylene-Blue, Chapman and $\mathrm{MH}$ medium and incubated at $37^{\circ} \mathrm{C}$ for 24 hours.

\section{Identification}

Gram staining was carried out directly on isolated colonies. Colonies with Gramnegative bacilli (GNB), Gram-positive bacilli (GPB) and Gram-positive cocci (GPC) were then selected. After purification, biochemical identification of GNB was carried out by seeding the API $20 \mathrm{E}$ gallery. For the identification of $S$. aureus, catalase, coagulase and DNase tests were carried out on Grampositive cocci. Catalase, oxidase, and urease tests were also performed on sporulate large Gram-positive bacilli for the identification of Bacillus spp.

\section{Statistical analysis}

All statistical analyses were performed using SPSS Statistics 21 software. Fisher's exact test was used to test the association between the Results of culture samples and different services at a 0.05 level of significance.

\section{Ethics approval and consent to participate}

The study was approved by the direction of Cotonou 5 Hospital (N/R $\mathrm{N}^{\circ} 019 / \mathrm{CSRHI}$ DIR/HM/17) dated 13 th January 2017). In the laboratory, protection and safety measures were guaranteed.

\section{Results and Discussion}

Of the total 165 samples analysed, $81.82 \%$ (n $=135$ ) were positive for bacteria and $18.18 \%$ $(\mathrm{n}=30)$ negative (Table 1$)$.

The distribution by services is presented in Table 1 . The greatest frequency of bacterial isolation was observed in Emergency (95\%) and the lowest proportion was found in the Operating Theater $(65.71 \%)$. There was not a statistically significant association between the Results of culture samples and different services $(\mathrm{F}=10.04 ; \mathrm{p}=0.06)$.

\section{Biochemical identification}

The study of biochemical characteristics revealed $49.77 \%$ Gram-positive bacteria (GPB), and 50.20\% Gram-negative bacteria (GNB) (Table 2). Gram-positive bacteria consisted of 3 different species. There were staphylococci (27.15\%) and Bacillus (22.62\%). Gram-negative bacteria had 27 
different species. There were $31.19 \%$ Enterobacteriaceae, $16.75 \%$ Non-fermenting Gram-negative bacilli (NFGNB). Only 2.26\% isolate belong to another genus of Gram Negative Bacilli was identified (Table 2).

\section{Repartition of species identified according to the service}

Species identified in survey services are presented in table 3. Acinetobacter baumannii (6.79\%), Bacillus spp (22.62\%), Escherichia coli (5.86\%) and Staphylococcus aureus $(18.55 \%)$ were present in all services (Table $3)$.

\section{Distribution of Gram-negative bacillus strains in categories of bacteria}

There were a total of 111 Gram-negative strains. Enterobacteriacecae (62.16\%), NFGNB (33.33\%) and $4.50 \%$ of other GNBwere identified (Figure 1).

\section{Distribution of identified GNB strains according to genus}

There were 69 genera that constituted the 111 strains of bacteria from Gram-negative bacillui group identified in the study. The most frequent were Enterobacter (14.41\%), followed by Acinetobacter (13.51\%) (Figure 2).

\section{Identified species of Gram-negative bacilli}

Gram-negative bacteria species are presented in Table 4. The predominant species were Acinetobacter baumannii (13.51\%).

\section{Distribution of distribution of NFGNB}

The NFGNB strains consisted of 18 species. Acinetobacter baumannii (40.54\%) and Pseudomonas oryzihabitans $(27.02 \%)$ are the most represented (Figure 3).
Inoculation of surface samples collected in Cotonou 5 Hospital yielded $81.82 \%$ positive bacterial cultures. The highest bacterial culture frequencies $(95 \%)$ were recorded for the intensive care unit and the emergency department. The traffic of the nursing staff and visitors in these hospital areas increases the likelihood of pathogen dissemination. The quality of air in these units is also important, as the airborne particles settle on the surfaces more quickly because they are bulky. However, the percentage of positive bacterial cultures obtained in the present study $(81.82 \%)$ is significantly higher than that $(31.4 \%)$ noted in a public hospital of Boufarik, Blida-Algerie (Kais et al., 2015). Overall, $18.18 \%$ of bacterial cultures were negative, with the majority of such cultures found in the operating room. The negative bacterial culture percentage obtained in this study is greater than $14 \%$ found at El Idrissi hospital in Kenitra, Morocco (Saouide et al., 2014). However, it is lower than $68.60 \%$ obtained by Kais et al., in their study. In Cotonou 5 Hospital, there is no statistically significant association between the culture findings pertaining to different surface samples and the hospital units in which these samples were taken $(\mathrm{F}=10.04, \mathrm{p}=0.06)$. Microorganisms were identified in all departments and there were $49.77 \%$ Gram-positive bacteria and $50.20 \% \quad$ Gram-negative bacteria. Acinetobacter baumannii, Bacillus spp., Escherichia coli and Staphylococcus aureus were consistently identified in all Cotonou 5 Hospital units (Table 3). Staphylococcus aureus colonizes frequently used hospital surfaces (Subbalakshmi, 2018). The omnipresence of coagulase-negative Bacillus spp. and Staphylococcus was also seen in the flora of the surfaces of El Idrissi Hospital in Kenitra, Morocco (Saouide et al., 2014). In the Cotonou 5 Hospital that served as the study site in this work, Staphylococcus (27.15\%) and Bacillus (22.62\%) were predominant. 
Fig.1 Distribution of 111 Gram-negative bacilli strains according to categories of bacteria

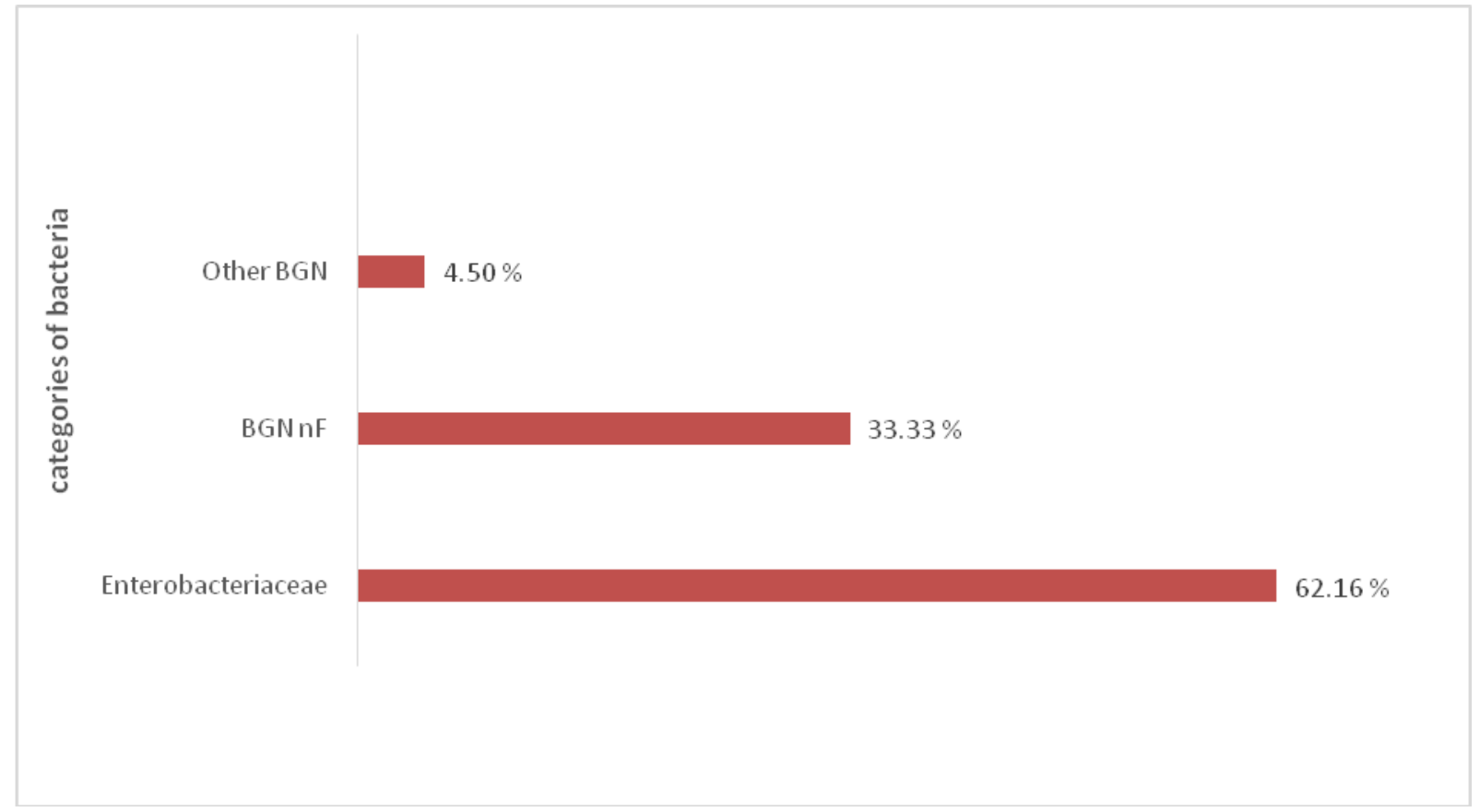

Fig.2 Distribution of Gram-negative bacilli according to genus

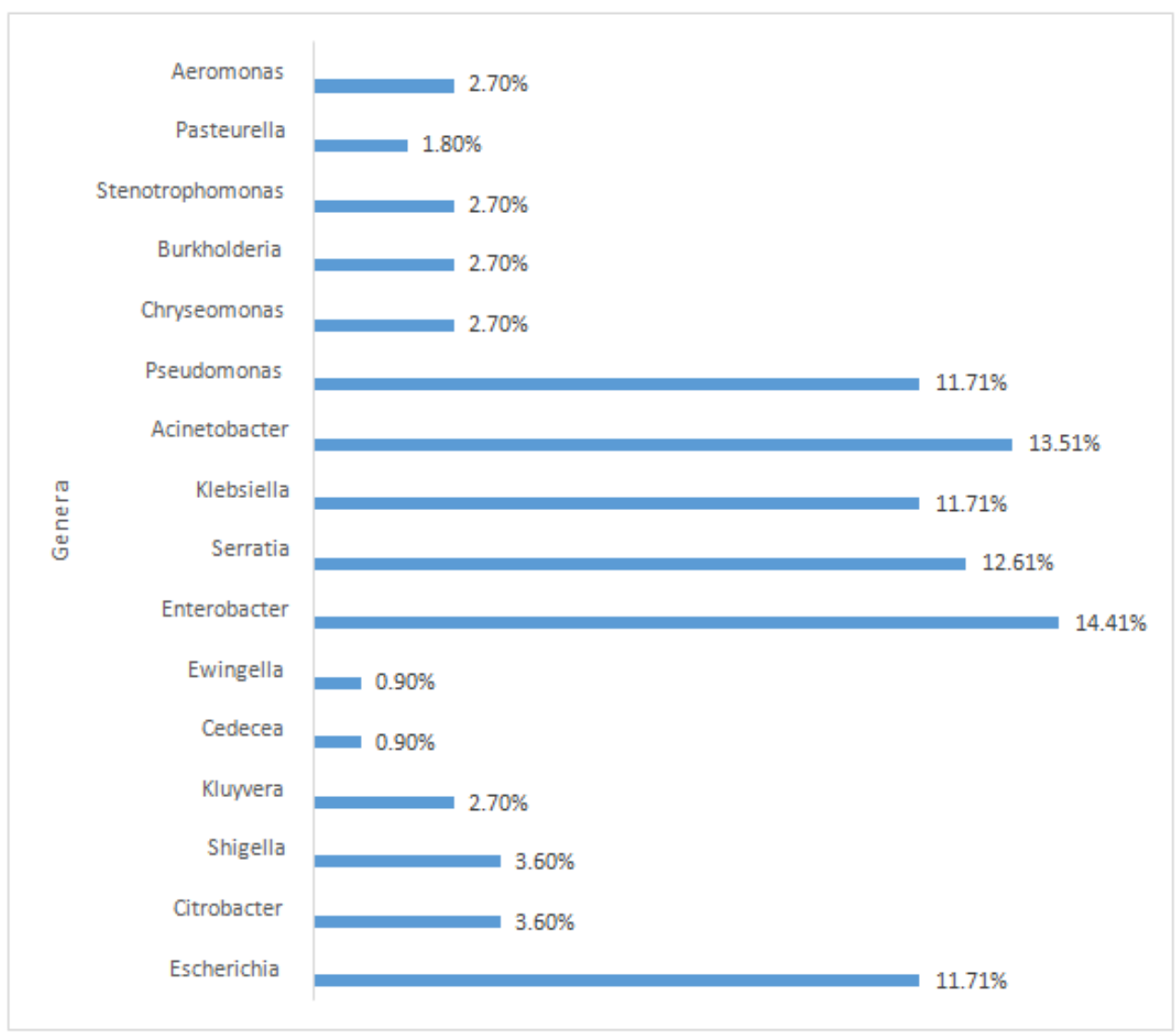


Fig.3 Distribution of the NFGNB

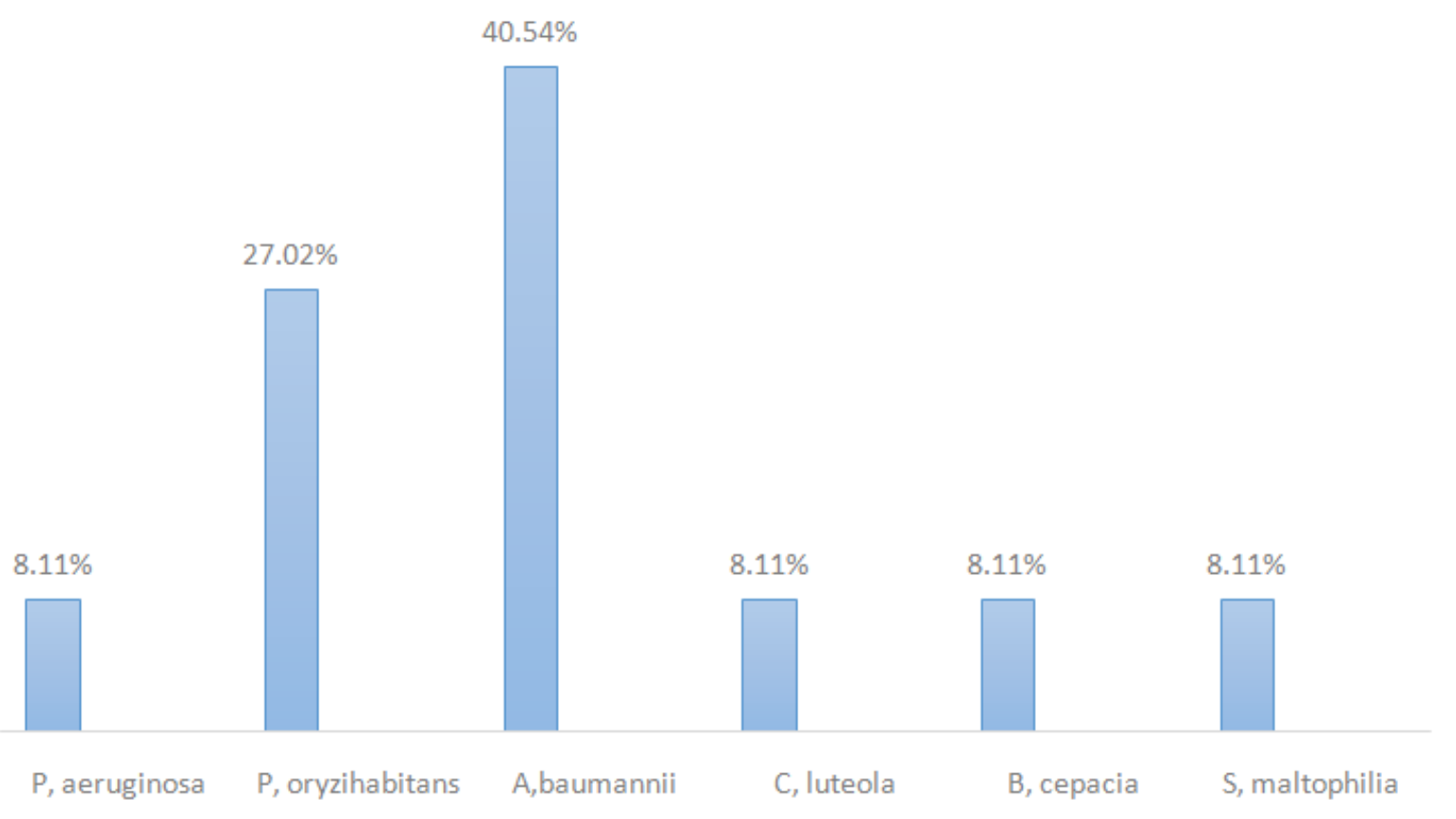

Table.1 Results of culture samples

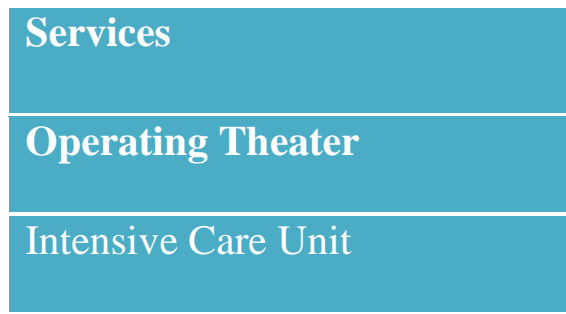

\begin{tabular}{|c|c|c|}
\hline \multicolumn{2}{|c|}{ Results of culture } & Numbers \\
\hline$(-)$ & $(+)$ & 35 \\
\hline 12 & 23 & \\
$(34.29 \%)$ & $(65.71 \%)$ & 20 \\
01 & 19 & \\
$(5 \%)$ & $(95 \%)$ & 30 \\
\hline 05 & 25 & 40 \\
$(16.67 \%)$ & $(83.33 \%)$ & \\
\hline 08 & 32 & 20 \\
$(20 \%)$ & $(80 \%)$ & 20 \\
\hline 03 & 17 & \\
$(15 \%)$ & $(85 \%)$ & 165 \\
\hline 01 & 19 & \\
\hline$(5 \%)$ & $(95 \%)$ & 135 \\
\hline 30 & $(81.82 \%)$ & \\
\hline
\end{tabular}

$(-)=$ negative environmental culture

$(+)=$ positive environmental culture 
Table.2 Repartition of species identified according to the group of bacteria

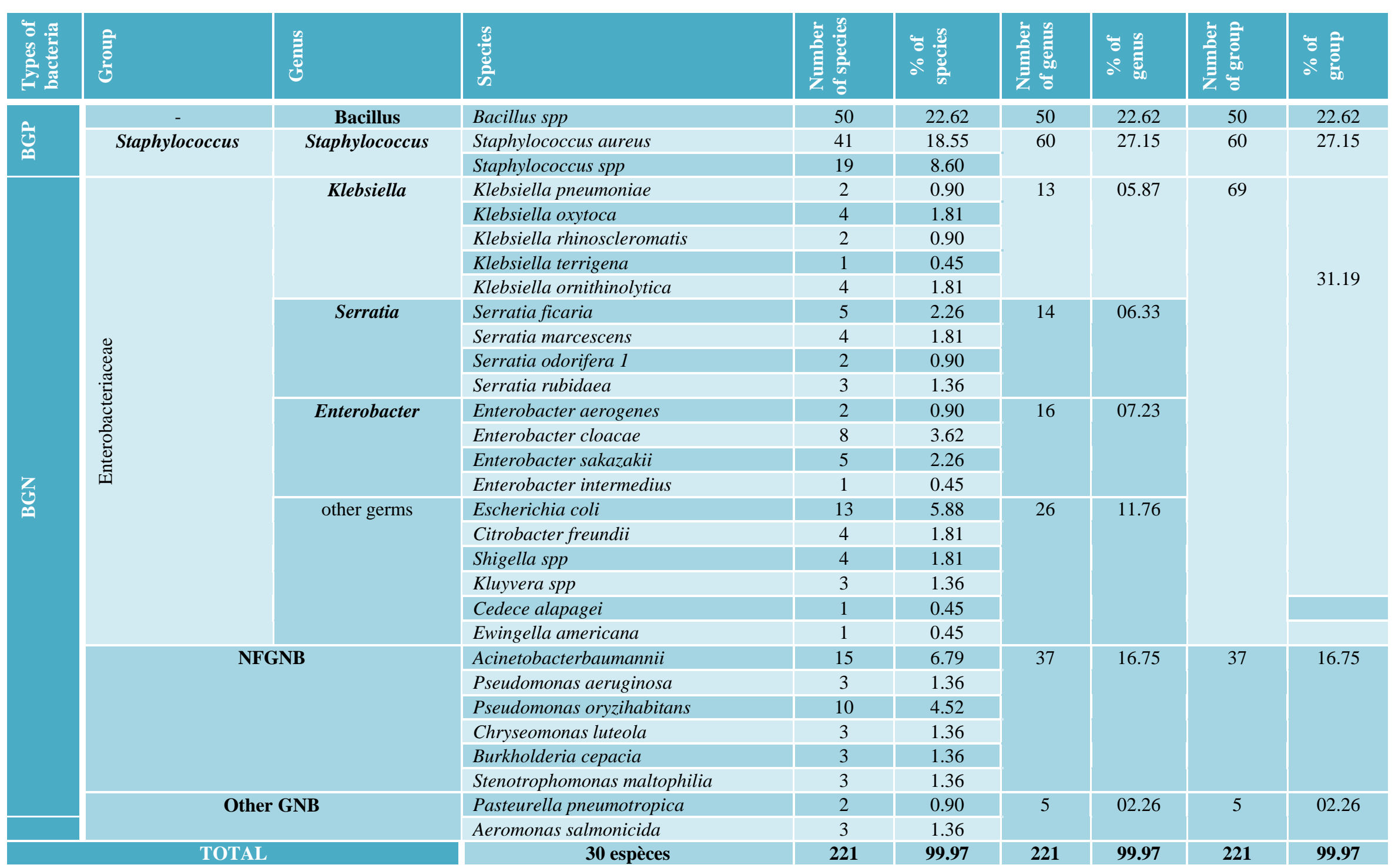

Types and groups of bacteria: GPB: Gram-positive bacteria; GNB: Gram-negative bacteria; NFGNB: Non-fermenting gram-negative bacilli 
Table.3 Repartition of species identified according to the services

\begin{tabular}{|c|c|c|c|c|c|c|c|c|}
\hline \multirow[t]{2}{*}{ species } & \multicolumn{6}{|c|}{$\begin{array}{c}\text { Number of species according to } \\
\text { the service }\end{array}$} & \multirow[t]{2}{*}{$\begin{array}{l}\text { Number } \\
\text { of species }\end{array}$} & \multirow[t]{2}{*}{$\%$ of species } \\
\hline & $\mathbf{A}$ & B & $\mathrm{C}$ & $\mathbf{D}$ & $\mathbf{E}$ & $\mathbf{F}$ & & \\
\hline Acinetobacter baumannii & 2 & 2 & 3 & 1 & 1 & 6 & 15 & 6.79 \\
\hline Aeromonas salmonicida & 1 & - & 1 & - & 1 & - & 3 & 1.36 \\
\hline Bacillus spp & 16 & 11 & 5 & 3 & 11 & 4 & 50 & 22.62 \\
\hline Burkholderia cepacia & - & - & 2 & 1 & - & - & 3 & 1.36 \\
\hline Citrobacter freundii & - & 2 & 1 & - & 1 & - & 4 & 1.81 \\
\hline Chryseomonas luteola & 1 & - & - & 1 & 1 & - & 3 & 1.36 \\
\hline Escherichia coli & 1 & 5 & 2 & 1 & 1 & 3 & 13 & 5.88 \\
\hline Enterobacter aerogenes & - & - & - & 1 & 1 & - & 2 & 0.90 \\
\hline Enterobacter cloacae & 1 & 1 & - & 2 & 1 & 3 & 8 & 3.62 \\
\hline Enterobacter sakazakii & 1 & 1 & 1 & 1 & - & 1 & 5 & 2.26 \\
\hline Enterobacter intermedius & - & 1 & - & - & - & - & 1 & 0.45 \\
\hline Klebsiella pneumoniae & - & 1 & - & - & - & 1 & 2 & 0.90 \\
\hline Klebsiella ornithinolytica & 2 & - & 2 & - & - & - & 4 & 1.81 \\
\hline Klebsiella rhinoscleromatis & - & - & 1 & 1 & - & - & 2 & 0.90 \\
\hline Klebsiella oxytoca & 1 & 1 & 2 & - & - & - & 4 & 1.81 \\
\hline Klebsiella terrigena & 1 & - & - & - & - & - & 1 & 0.45 \\
\hline Ewingella americana & - & - & 1 & - & - & - & 1 & 0.45 \\
\hline Cedecealapagei & - & - & 1 & - & - & - & 1 & 0.45 \\
\hline Kluyvera spp & - & 1 & - & 1 & 1 & - & 3 & 1.36 \\
\hline Pasteurella pneumotropica & - & 1 & 1 & - & - & - & 2 & 0.90 \\
\hline Pseudomonas oryzihabitans & 2 & - & 2 & 3 & 1 & 2 & 10 & 4.52 \\
\hline Pseudomonas aeruginosa & 2 & 1 & - & - & - & - & 3 & 1.36 \\
\hline Serratia ficaria & 1 & 1 & 1 & 1 & - & 1 & 5 & 2.26 \\
\hline Serratia marcescens & - & 2 & 1 & 1 & - & - & 4 & 1.81 \\
\hline Serratia odorifera 1 & - & - & 1 & - & 1 & - & 2 & 0.90 \\
\hline Serratia rubidaea & - & 1 & 1 & - & 1 & - & 3 & 1.36 \\
\hline Shigella spp & 2 & 1 & 1 & - & - & - & 4 & 1.81 \\
\hline Staphylococcus aureus & 11 & 6 & 5 & 7 & 3 & 9 & 41 & 18.55 \\
\hline Staphylococcus spp & - & 2 & 2 & 6 & 6 & 3 & 19 & 8.60 \\
\hline $\begin{array}{l}\text { Stenotrophomonas } \\
\text { maltophilia }\end{array}$ & 1 & 1 & - & - & - & 1 & 3 & 1.36 \\
\hline Total & 46 & 42 & 37 & 31 & 31 & 34 & 221 & 99.97 \\
\hline
\end{tabular}

Services : A : Hospitalization adults; B : Maternity ; C : Pediatrics ; D : Emergency services; E : Operating Theater; F : Intensive Care Unit. 
Table.4 Number of Gram-negative bacilli identified in the sampling of hospital surfaces

\begin{tabular}{|l|}
\hline Species \\
\hline Klebsiella pneumoniae \\
\hline Klebsiella oxytoca \\
\hline Klebsiella rhinoscleromatis \\
\hline Klebsiella terrigena \\
\hline Klebsiella ornithinolytica \\
\hline Serratia ficaria \\
\hline Serratia marcescens \\
\hline Serratia odorifera 1 \\
\hline Serratia rubidaea \\
\hline Enterobacter aerogenes \\
\hline Enterobacter cloacae \\
\hline Enterobacter sakazakii \\
\hline Enterobacter intermedius \\
\hline Escherichia coli \\
\hline Citrobacter freundii \\
\hline Shigella spp \\
\hline Kluyvera spp \\
\hline Cedecea lapagei \\
\hline Ewingella americana \\
\hline Acinetobacter baumannii \\
\hline Pseudomonas aeruginosa \\
\hline Pseudomonas oryzihabitans \\
\hline Chryseomonas luteola \\
\hline Burkholderia cepacia \\
\hline Stenotrophomonas maltophilia \\
\hline Pasteurella pneumotropica \\
\hline Aeromonas salmonicida \\
\hline Total \\
\hline
\end{tabular}

This prevalence was also recorded in 2009 in Alzahra Hospital, Isfahan, Iran (Jalalpoor et al., 2009).

In the group of identified staphylococci, there is a preponderance of Staphylococcus aureus (18.55\%) against $08.60 \%$ Staphylococcus spp. This proportion of Staphylococcus aureus is low compared to the $20 \%$ found on the surfaces of El Idrissi hospital by Saouide et al., (2014). MRSA are particularly worrisome in hospitals (Hsu et al., 1988). MRSA is also

\begin{tabular}{|c|c|}
\hline Number of species & $\%$ of species \\
\hline 2 & 01.80 \\
\hline 4 & 03.60 \\
\hline 2 & 01.80 \\
\hline 1 & 00.90 \\
\hline 4 & 03.60 \\
\hline 5 & 04.50 \\
\hline 4 & 03.60 \\
\hline 2 & 01.80 \\
\hline 3 & 02.70 \\
\hline 2 & 01.80 \\
\hline 8 & 07.21 \\
\hline 5 & 04.50 \\
\hline 1 & 00.90 \\
\hline 13 & 11.71 \\
\hline 4 & 03.60 \\
\hline 4 & 03.60 \\
\hline 3 & 02.70 \\
\hline 1 & 00.90 \\
\hline 1 & 00.90 \\
\hline 15 & 13.51 \\
\hline 3 & 02.70 \\
\hline 10 & 09.01 \\
\hline 3 & 02.70 \\
\hline 3 & 02.70 \\
\hline 3 & 02.70 \\
\hline 2 & 01.80 \\
\hline 3 & 02.70 \\
\hline 111 & 99.94 \\
\hline
\end{tabular}

identified in clinical specimens, including pus, obtained from several patients (Rozina et al., 2018). Staphylococcus aureus is a pathogen that survives for months on dry surfaces (Axel et al., 2006), and methicillinresistant Staphylococcus aureus (MRSA) survives for several days in hospital settings (Huang et al., 2012).

In a study examining the relationship between environmental contamination with MRSA and its acquisition by patients, 35\% of MRSA 
isolated from patients and their environment was indistinguishable (Hardy et al., 2006). The identification of Staphylococcus aureus species in the environment of Cotonou 5 Hospital indicates the existence of the infectious risk associated with this pathogen. Based on the analysis results, enterobacteria were predominant $(62.16 \%)$ in Gram-negative bacilli, followed by $33.33 \%$ non-fermenting Gram-negative bacilli (NFGNB). Gramnegative bacilli (GNB) acquire genes that code for antibiotic resistance mechanisms and thus exacerbate the resulting infections (Ruppé et al., 2015). The rate of enterobacteria isolated in our study is higher than the $10.70 \%$ isolated by Jalalpoor (2011) and is lower than $74.51 \%$ reported by Debabza (2015). Among the isolated GNB species, Acinetobacter baumannii is predominant (13.51\%), followed by Escherichia coli at $11.71 \%$ (Table 4). Escherichia coli is a formidable pathogen in certain infections, including those of the urinary tract (Eman et al., 2018), sepsis, pneumonia, neonatal meningitis (Hassan et al., 2015, Lausch et al., 2013). In the group of NFGNB, Acinetobacter baumannii (40.54\%) is predominant, followed by Pseudomonas oryzihabitans $(27.02 \%)$ (Figure 3 ). These NFGNB are also found in hospital-based fluid specimens and have been identified in 121 NFGNB for 1850 clinical specimens in tertiary care hospital (Siddiqui et al., 2018). NFGNB are bacteria that are generally considered opportunistic pathogens selected by repeated and prolonged antibiotic treatments (Ferroni et al., 2003). Acinetobacter baumannii is resistant to several antibiotics (Howard et al., 2012, Weber et al., 2015), and its epidemic distribution is due to its manual transmission and survival in the hospital environment (Lahsoune et al., 2007; Ducel et al., 2002). The level of Acinetobacter baumannii identified in NFGNB in our study is higher than the $28.57 \%$ reported by Liazid (2016) for
Tlemcen hospital in Algeria. Acinetobacter baumannii can persist for three days to five months and can survive on dry surfaces (Kramer et al., 2006, Otter et al., 2011). It can cause high mortality, up to $35 \%$ (Antunes et al., 2014). The diversity of the germs identified in the analysis of hospital surfaces at Cotonou 5 Hospital provides information on its quality of hospital hygiene. The presence of Acinetobacter baumannii, Bacillus spp., Escherichia coli and Staphylococcus aureus in various units reflects hygiene inadequacies in the hospital. Thus, improvements to the cleaning practices and disinfection of hospital surfaces are essential (Weber et al., 2013). Use of $1 \%$ hypochlorite is recommended for this purpose (Subbalakshmi, 2018).

Severe healthcare-associated infections constitute a challenge for patient safety in hospitals. Several germs are responsible. Our study revealed the presence of nosocomial pathogens on hospital surfaces of Cotonou 5 Hospital. In this context, the identification of a variety of germs, including Bacillus spp. and Escherichia coli in certain hospital units signifies insufficient quality of cleaning and disinfection of the patient's environment. This bacterial contamination of the hospital environment requires better management of the infectious risk and reinforcement of the rigorous hospital hygiene measures.

\section{References}

Alonso-Aguilar NM, Juarez-Enriquez SR, Castro-Escarpulli G, Rivera G, Bocanegra-Garcia V, Guo X, LunaHerrera J, Aguilera-Arreola MG. A 2017. Etiology and Significance of Hospital-Acquired Infections in Mexico. Clinical Laboratory. 63(2): 207-218.

Antunes LC, Visca P, Towner KJ. 2014. Acinetobacter baumannii: evolution of a 
global pathogen. Pathogens and Disease. 71(3): 292-301.

Axel K, Ingeborg S, Günter K. 2006. How long do nosocomial pathogens persist on inanimate surfaces? BioMed Central Infectious Diseases. 6: 130.

Boyce JM. 2007. Environmental contamination makes an important contribution to hospital infection. J Hosp Infect. (65) 2:50-4.

Boyce JM. Potter-Bynoe G, Chenevert C, King T. 1997. Environmental contamination due to methicillinresistant Staphylococcus aureus: possible infection control implications. Infect Control Hosp. Epidemiol. 18(9): 622-7.

Cornejo-Juárez P.' D. Vilar-Compte, C. PérezJiménez, S.A. Namendys-Silva, S. Sandoval-Hernández, P. VolkowFernández. 2015. The impact of hospital-acquired infections with multidrug-resistant bacteria in an oncology intensive care unit. International Journal of Infectious Diseases. 31:31-34

Debabza M. 2015. Emergence en milieu hospitalier des bacilles Gram négatifs multirésistants aux antibiotiques : étude bactériologique et moléculaire. Thèse de Doctorat en Microbiologie, Faculté des Sciences, Université Badji MokhtarAnnaba, Algérie. Pp. 259.

Defez C, Fbro-Peray P, Cazaban M. Boudemaghe T, Sotto A, Daurès JP 2008. Additional direct medical cost of nosocomial infections: an estimation from a cohort of patients in a French university hospital. Journal of Hospital Infection; 68(2): 130-136.

Ducel. G, Fabry. J, Nicolle L. 2002. Prevention of hospital acquired infection. A practical guide Asian pacific society of infection control. 2nd edn. Pp. 17-19.
Eman Elsayed Hegazy, Rasha Abd El-Hamid Alam El-Din, Ahmed Mostafa Amin, Fawkia Mohamed Mahgoub and Samir Abd El-Hakeem El-Gamal. 2018. Microbiological Profile of Urinary Tract Infections with special Reference to Antibiotic Susceptibility Pattern of Escherichia coli Isolates. Int.J.Curr. Microbiol.App.Sci. 7(02): 911-920. doi: https://doi.org/10.20546/ijcmas.2018.70 2.115 .

Ferroni A, Sermet-Gaudelus I, Abachin E, Quesnes G, Lenoir G, Berche P, Gaillard J.L. 2003. Caractéristiques phénotypiques et génotypiques des souches atypiques de bacilles à Gram négatif non fermentant isolées chez des patients atteints de mucoviscidose. Pathologie Biologie., 51: 405-411.

Galvin S, Dolan A, Cahill O, Daniels S, Humphreys H. 2012. Microbial monitoring of the hospital environment: why and how. Journal of Hospital Infection. 82 (3): 143-151.

Hamza R. 2010. Épidémiologie des infections associées aux soins. Revue Tunisienned' Infectiologie. 4:1-4.

Hardy KJ, Oppenheim BA, Gossain S, Gao F, Hawkey PM. 2006. A study of the relationship between environmental contamination with methicillin-resistant Staphylococcus aureus (MRSA) and patients' acquisition of MRSA. Infect Control Hosp. Epidemiol. 27(2):127-32.

Hassan AK, Aftab A, Riffat M. 2015. Nosocomial infection and their control strategies. Asian Pacific Journal of Tropical Biomedicine. 5(7): 509-514

Howard A, O'Donoghue M, Feeney A, Sleator RD. 2012. Acinetobacter baumannii. An emerging opportunistic pathogen. Virulence. 3(3): 243-250.

Hsu CC, Macaluso CP, Special L. 1988. High rate of methicillin resistance of staphylococcus aureus isolate from 
hospitalized nursing home patients. Arch Intern Med.148 (3): 569-70.

Huang XZ, Frye JG, Chahine MA, Glenn LM, Ake JA, Su W, Nikolich MP, Lesho EP. 2012. Characteristics of plasmids in Multi-Drug-Resistant Enterobacteriaceae isolated during prospective surveillance of a newly opened hospital in Iraq. PLoS One. 7(7): e40360

ISO 14698 - 1:2003. Cleanrooms and associated controlled environments Biocontamination control - Part 1: General principles and methods.

Jalalpoor S. 2011. Study of the antibiotic resistance pattern among the bacterial isolated from the hospital environment of Azzahra Hospital, Isfahan, Iran. African Journal of Microbiology Research. 5 (20): 3317-3320.

Jalalpoor Sh, Kasra Kermanshahi R, Nouhi AS, Zarkesh Esfahani H. 2009. The comparative frequency of -lactamase production and antibiotic susceptibility pattern of bacterial strains isolated from staff hands and hospital surfaces in Alzahra Hospital-Isfahan. Iranian. J. Med. Microbiol., 3(4):37-45.

Kais H., Hamaidi-Chergui F., Hamaidi M.S., Bengherbia A., OuldMahieddine A. 2015. Surfaces et dispositifs medicaux dans differents services de l'etablissement public hospitalier de Boufarik: état microbiologique (BlidaAlgerie). Rev. Microbiol. Ind. San etEnvironn. 9 (1): 80-97.

Kramer A, Schwebke I, Kampf G. 2006. How long do nosocomial pathogens persist on inanimate surfaces? A systematic review. BMC Infectious Diseases. 6: 130

Lahsoune M, Boutayeb H, Zerouali K, Belabbes H, El Mdaghri N. 2007. Prévalence et état de sensibilité aux antibiotiques d'Acinetobacter baumannii dans un CHU marocain.
Médecine et maladies infectieuses. 37: 828-831.

Lausch KR, Fuursted K, Larsen CS, Storgaard M. 2013. Colonization with multiresistant Enterobacteriaceae in hospitalised Danish patients with a history of recent travel: a crosssectional study. Travel Medicine and Infectious Disease. 11(5): 320-330.

Liazid A. 2016. Etude de la résistance aux antibiotiques des bactéries à Gram négatif non fermentant au niveau du C.H.U de Tlemcen. Mémoire de magister. Maitrise de la qualité microbiologique et du développement microbien. Université Abou BekrBelkaid-Tlemcen, Algérie.

Marty N. 2010. Les flores de 1'environnement humain. HygièneHospitalière. Suramps Medical, 3: Pp25-36.

Oliveira AC, Damasceno QS. 2010. Surfaces of the hospital environment as possible deposits of resistant bacteria: a review. Revista da Escola de Enfermagem da U S P. 44 (4): 1112-1117.

Otter JA, Yelp S, French GL. 2011. The role played by contaminated surfaces in the transmission of nosocomial pathogens. Infection Control and Hospital Epidemiology; 32(7): 687-699.

Ouendo E-M, Saïzonou J, Dégbey C., GléléKakai C., Glélé Y, Makoutode M. 2015. Gestion du risque infectieux associé aux soins et services au Centre National Hospitalier et Universitaire Hubert Koutoukou Maga de Cotonou (Bénin), Int. J. Biol. Chem. Sci.9(1) : 292-300.

Parneix P. 2010. Les infections nosocomiales associées aux soins. In Hygiène Hospitalière. Sauramps Medical. 3: 3746.

Ragini Ananth Kashid and Kausalya Raghuraman. 2018. Mupirocin Resistance in Staphylococcus aureus Isolated from the Anterior Nares of 
Health Care Workers, in a Tertiary Care Hospital. Int.J.Curr.Microbiol.App.Sci. 7(02): 293-298. doi: https://doi.org/10.20546/ijcmas.2018.70 2.038 .

RozinaArshi Khan, MahwishJawaid and Mohammed Khaleel. 2018. Bacteriological Profile and Antibiogram of Isolates from Pus Samples in a Tertiary Care Centre. Int.J.Curr. Microbiol.App.Sci. 7(01): 387-394.

Ruppé E, Woerther P L, Barbier F. 2015. Mechanisms of antimicrobial resistance in Gram-negative bacilli. Annals of Intensive Care. 5: 21.

Sangeetha, K.T., S. Sreeja and Ruby Thomas. 2018. A Prospective Study Estimating the Mupirocin Resistance in Health Care Providers with MRSA Nasal Carriage in a Tertiary Care Hospital in Rural South India. Int.J.Curr.Microbiol.App.Sci. 7(01): 659-663. doi: https://doi.org/10.20546/ ijcmas.2018.701.080.

Saouide el ayne Nabila, EchchelhAdil, ChaouchAbedelaziz, Auajjar Nabila, Hamama Samir, Soulaymani Abdelmajid. 2014. Rôle de l'environnement hospitalier dans la prévention des infections nosocomiales: surveillance de la flore des surfaces à l'hôpital El Idrissi de Kenitra- maroc. European Scientific Journal. (10): 9; $238-247$
Siddiqui HeenaKausar, V.P. Bansal and Bhalchandra, M. 2018. Prevalence and Susceptibility Profiles of NonFermentative Gram-Negative Bacilli Infection in Tertiary Care Hospital. Int.J.Curr.Microbiol.App.Sci. 7(01): 740-744. doi: https://doi.org/10.20546/ ijcmas.2018.701.089.

Soussy C. J. 2010. Principaux microorganismes responsable: les bactéries. HygièneHospitalière. Sauramps Medical, 3: p69-78.

Subbalakshmi, E. 2018. Surveillance of Hospital Acquired Infection from Frequently Handled Surfaces in a Tertiary Care Teaching Hospital. Int.J.Curr.Microbiol.App.Sci. 7(02): 860-866. doi: https://doi.org/10.20546/ ijcmas.2018.702.108.

Weber BS, Harding CM, Feldman MF. 2015. Pathogenic Acinetobacter: from the Cell Surface to Infinity and Beyond. Journal of Bacteriology. 198 (6): 880-887.

Weber DJ, Anderson D, Rutala WA. 2013. The role of the surface environment in healthcare-associated infections. Curr Opin Infect Dis. 26(4):338-44.

Weber DJ, Rutala WA, Miller MB, Huslage K, Sickbert-Bennett E. 2010. Role of hospital surfaces in the transmission of emerging health care-associated pathogens: norovirus, Clostridium difficile, and Acinetobacter species. Am J Infect Control. 38(5 Suppl 1):S25-33.

\section{How to cite this article:}

F Cyr Doscoph Afle, Alidéhou Jerrold Agbankpe, Roch Christian Johnson, Olivia Houngbegnon, Sègbè Christophe Houssou and Honoré Sourou Bankole. 2018. Hospital Acquired Infection: Bacteriological Profile of Species from Environmental Surfaces of Cotonou 5 Hospital in South Benin (West Africa). Int.J.Curr.Microbiol.App.Sci. 7(04): 15031515. doi: https://doi.org/10.20546/ijcmas.2018.704.169 